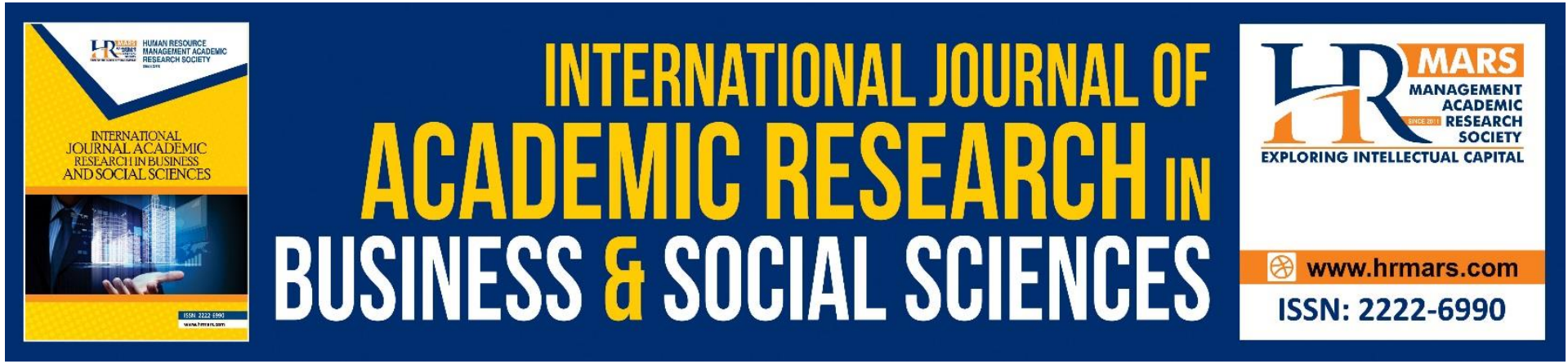

\title{
CSR and Employee Performance: A Systematic Literature Review Approach
}

\section{Sharifah Nazura Syed Noh}

To Link this Article: http://dx.doi.org/10.6007/IJARBSS/v11-i9/11075

DOI:10.6007/IJARBSS/v11-i9/11075

Received: 03 July 2021, Revised: 04 August 2021, Accepted: 30 August 2021

Published Online: 17 September 2021

In-Text Citation: (Noh, 2021)

To Cite this Article: Noh, S. N. S. (2021). CSR and Employee Performance: A Systematic Literature Review Approach. International Journal of Academic Research in Business and Social Sciences, 11(9), 863-872.

Copyright: () 2021 The Author(s)

Published by Human Resource Management Academic Research Society (www.hrmars.com)

This article is published under the Creative Commons Attribution (CC BY 4.0) license. Anyone may reproduce, distribute, translate and create derivative works of this article (for both commercial and non-commercial purposes), subject to full attribution to the original publication and authors. The full terms of this license may be seen at: http://creativecommons.org/licences/by/4.0/legalcode

Vol. 11, No. 9, 2021, Pg. 863 - 872

Full Terms \& Conditions of access and use can be found at http://hrmars.com/index.php/pages/detail/publication-ethics 


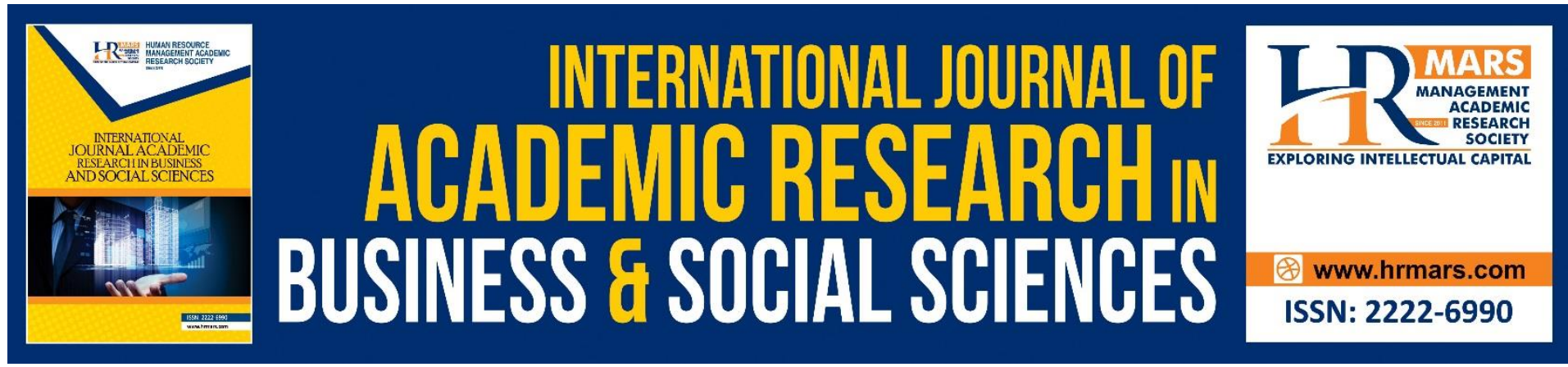

\title{
CSR and Employee Performance: A Systematic Literature Review Approach
}

\author{
Sharifah Nazura Syed Noh \\ Faculty of Business and Management, Universiti Teknologi MARA, Cawangan Negeri \\ Sembilan, Kampus Rembau.
}

\begin{abstract}
CSR is one of the most important social factors that may influence employees' commitment, engagement, and job satisfaction. It also acts as a foundation stone for building employees' attitudes and behaviour. However, there are still insufficient studies that systematically review the existing literature on CSR and employee performance. Hence, this article systematically reviewed articles on the impact of CSR on employee performance. Guided by the PRISMA Statement (Preferred Reporting Items for Systematic reviews and Meta-Analyses) review method, the articles were selected from the leading database, Scopus and a supporting database, Google Scholar. The review mainly focused on the moderators and the impact of CSR on employee performance. The study offered several significant contributions for practical purposes and body of knowledge to encourage companies and organizations to implement activities that promote employee welfare to increase their performance.
\end{abstract}

Keywords: Corporate Social Responsibility, Employee Performance

\section{Introduction}

According to Caroll (1979), economic responsibilities require businesses to be profitable, provide good jobs for employees, and produce goods and services desirable in society. The definition of CSR can be illustrated in a pyramid of four CSR dimensions which lists the social responsibility of business, namely economic, legal, ethical, and discretionary expectations.

Employee performance refers to the quality, quantity, expertise, or innovation of an individual's contributions to complete works following their responsibilities over a set period (Muda, Rafiki \& Harahap, 2014). One of the assessable elements of organizational performance to accomplish goals is employee performance which is measured based on their productivity level. Employees also play an essential role in determining the organization's success and failure (Harun, Isa and Arjuna, 2014).

It has been observed that there is a significant relationship between employees' perception towards CSR and their attitudes as well as engagement (Ahmad et al., 2019; Albdour \& Altarawneh, 2012; Harun et al., 2015; Osita-Njoku et al., 2020; Suganthi, 2019). According to Nezhad et al (2015), employees perceived philanthropic and ethical CSR activities as more important than economic and legal CSR activities. 
The study on employees' perception towards CSR is essential to increase employee performance, and create a harmonious and fair working environment, specifically among Islamic financial institutions. With increasing numbers of workers every year, creating CSR awareness among employees is therefore essential because the success of an organization depends on its employees' efficiency and productivity (George, 2019).

\section{CSR And Employee Performance}

Various studies have examined the direct effect of Corporate Social Responsibility on employee performance (Albdour \& Altarawneh, 2012; Harun, Isa and Arjuna, 2015; Ahmad,Magda and Shahzad, 2019; Suganthi, 2019; Agnes et. Al., 2020). However, the studies produced inconsistent results on how CSR impacts employee performance.

A study by Rahman (2014) demonstrated that employees CSR attitudes in Bangladesh's banking industry positively impact their job satisfaction and the perceived external prestige. Agnes (2020) also found that employees would effectively perform their tasks when organizations perform their internal Corporate Social Responsibility (CSR). This is because the welfare package serves as a morale booster for employees. Furthermore, a study conducted by Harun,Isa and Arjuna (2015) also mentioned that CSR significantly affects employees' behaviour and their fulfilment of fairness. Interestingly, the study also revealed that most organizations do not know that implementing CSR program would positively impact employees' behaviour. In addition, the study done by Namjoofard (2014) on factors of employee-centred CSR and their relationship with the employees' motivation towards generating innovation concluded that employee-centred CSR factors of employees involvement in decision making and rewards contribute significantly to creating innovation.

\section{Research Gap in Existing Studies Related to CSR and Employee Performance}

The issue of how CSR and employee performance are related has attracted the attention of many researchers who have examined it from multiple perspectives. Although many studies focused on CSR and employees, not many scholars systematically reviewed the existing studies. A systematic review is one of the robust processes to review existing literature in a more organized way.

Reviewing past studies systematically is essential. In comparison to the systematic review, Robinson \& Lowe (2015) asserted that a formal literature review has the risk of being incomprehensive, is highly susceptible to reviewer bias, and seldom considers differences in the quality of studies. The present paper attempts to contribute to the existing body of knowledge by conducting a systematic literature review on CSR and employee performance. A systematic review is one of the ways to review existing literature in more systematic ways.

\section{Significance of the Study}

Employees are sceptical about organizations' CSR practices, so organizations need to really do what they claim they are doing. In a recent study, Deloitte (2015) found that employees overwhelmingly believe that business needs a reset by paying as much attention to people and purpose as it does to products and profit. Based on a study done by Tarigan, Susanto \& Hatane (2020), Corporate Social Responsibility is proven to positively affect the employees' work-life balance. It is also proven that CSR activities significantly impact employee organizational commitment, organizational performance, employee turnover intentions, and entry preference (Zahid et al., 2017) 
Thus, this study will help the executives to formulate methods in order to maintain high standards of employee efficiency thus enabling employees to perform excellently. Furthermore, it will allow the management of the companies/organizations to devise plans and strategies to ensure stellar employee performance. Moreover, it will help companies assess the impact of current job design on its employees and its relation to their performance, therefore making necessary improvements. As for the employees, this study is significant in ensuring or implanting a good work design, and will enable the employees to perform outstandingly.

\section{Methodology}

This section discusses the method used to retrieve articles related to CSR and employee performance. The PRISMA method, which includes resources from Scopus and Google Scholar, was used to conduct the systematic review, and determine the eligibility and exclusion criteria for this study.

There are four stages involved in the systematic review process (Moher et al., 2009). All the processes will be explained in the light of this study. The first stage involved the process of identifying keywords used for the search process. Generally, identification is a process to search any synonym, related terms, and variation for the study's main keywords. In the context of this study, the keywords were Corporate Social Responsibility and employee performance. It aims at providing more options for the selected databases in order to search for more ideas relevant to the issue of Corporate Social Responsibility and employee performance. The second stage was screening. At this stage, from 205 articles eligible to be reviewed, 168 were removed. The third stage was eligibility, whereby the full articles were accessed. After careful examination, a total of 37 articles were excluded as some did not focus on employee performance and were not empirical articles. The last stage was inclusion whereby a total of 11 articles were selected for further review in the SLR table. 

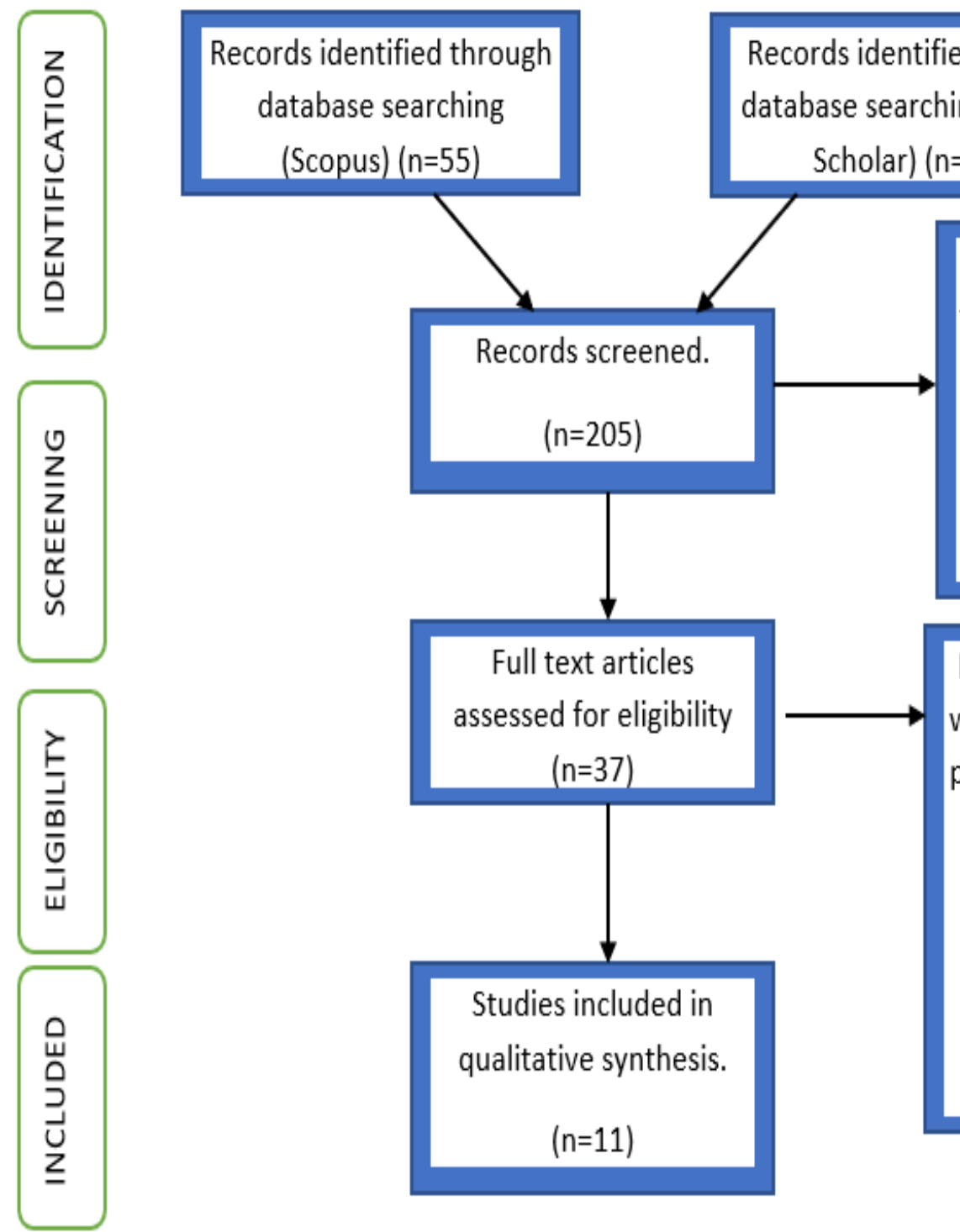

Records excluded as they were published before 2015 and nonEnglish documents, proceeding papers. $(n=168)$

Figure 1: The flow of diagram adapted from (Moher et al., 2009) 
Table 1: Results of the Identification Process

\begin{tabular}{|l|l|l|}
\hline Section & Main keywords & Enriched keywords \\
\hline performance & $\begin{array}{l}\text { CSR } \\
\text { Employee } \\
\text { performance }\end{array}$ & $\begin{array}{l}\text { responsibility= authority, duty, obligation } \\
\text { employee = labourer, staff member, worker } \\
\text { performance= achievement }\end{array}$ \\
& $\begin{array}{l}\text { Scopus: } \\
\text { TITLE-ABS-KEY (corporate* AND social* AND } \\
\text { responsibility* AND performance* AND } \\
\text { systematic* literature* review*) 57 }\end{array}$ \\
& $\begin{array}{l}\text { TITLE-ABS-KEY (corporate* AND social* AND } \\
\text { (responsibility* OR authority*) AND } \\
\text { (employee* OR staff* OR worker*) AND } \\
\text { (performance* OR achievement*) }\end{array}$ \\
& $\begin{array}{l}\text { GS: } \\
\text { Click advance search }\end{array}$ \\
&
\end{tabular}

\section{Results and Discussion}

This study focused on reviewing the relationship between CSR and employee performance. Previously, numbers of studies have examined the direct impact of Corporate Social Responsibility on employee performance (Zia Anam, 2015; Story \& Castanheira, 2019; OsitaNjoku et al., 2020; Chaudhary, 2020; Ali et al., 2020; Sarfraz et al., 2018; Nkeobuna \& Ugoani, 2020; Nazir et al., 2021). The review resulted in three main themes: Internal Corporate Social Responsibility and employee performance, moderators of CSR, and lastly, the impact of CSR on employee performance.

\section{Internal Corporate Social Responsibility and Employee Performance}

Some of the reviewed articles examined how different CSR practices can influence individual performance by using the internal CSR to identify the impact on employee performance. Zia Anam (2015) who conducted a study on the effect of internal Corporate Social Responsibility comprised of employee empowerment, training and development, work-life balance and health, and safety of employees, revealed that CSR significantly impacts individual performance. Besides that, Story \& Castanheira (2019), also examined the predictor of internal CSR, in which the study stated that organizational practice is significantly related to the betterment of working conditions. Specifically, factors of career opportunities, familyfriendly policies, training and development, and diversity management contribute to the increase of performance among employees, and there is a direct link between perceptions of external CSR and employee performance (Story \& Castanheira, 2019)., It was also found in this study that job satisfaction partially mediates the relationship between CSR and employee performance, and internal CSR is related to higher performance via job satisfaction, supporting complete mediation.

The study conducted by Osita-Njoku et al (2020) explored the impact of internal corporate responsibility (ICSR) of Nigeria National Petroleum Corporation (NNPC) on employee performance. The concept of ICSR practices includes protecting the employees' rights, health 
and safety policies, providing work-life balance programmes, conducting employee training, ensuring equal opportunity policy, etc. The findings from this study revealed that internal Corporate Social Responsibility is essential in encouraging employee performance. The provision of healthcare services has significantly reduced employees' absenteeism, and employee training has led to the increase of employees' effectiveness at NNPC. The concept of ICSR practices also has helped the organization to meet its employees' psychological needs as it promotes the perception of organizational support among employees.

\section{Moderators of CSR}

Some of the researchers have used the moderator variable to study the impact of CSR on employee performance. Chaudhary (2020) used gender and CSR importance as the moderator to study the effects of CSR on employee performance. The author believed that employees' social responsible behaviour is essential for businesses and correlates with their performance behaviours. The author found that the impact of perceived CSR on employee performance was not contingent on their gender as the relationship was found to be equally strong for both women and men. In Pakistan, manufacturing companies consider CSR practices as a relevant factor in increasing their identification with companies and is a significant predictor of their performance (Ali et al., 2020). This study used employee engagement to mediate the association of CSR and employee performance. The result revealed that CSR directly impacts employee performance and engagement, and confirmed that Employee Engagement partially mediates the association of CSR and employee performance.

Sarfraz et al (2018) used the mediating role of organizational justice between employees' perception towards CSR and employee outcomes in their study. It was found from the study that CSR improves a corporation reputation for potential employees, impacts employee performance, and enhances corporate prestige and organizational image in the view of external viewers (Sarfraz et al., 2018). This study revealed that employees' perception towards Corporate Social Responsibility has a significant association with organizational justice. The relationship between these variables was also tested, and it was established that CSR does not only improve a corporation reputation for potential employees, but also impacts employee job performance

\section{Impact of CSR on Employee Performance}

Many studies have revealed the significant impact of CSR on employees performance (Chaudhary, 2020; Nkeobuna \& Ugoani, 2020; Mulej et al., 2020; Sarfraz et al., 2018; Ali et al., 2020; Nazir et al., 2021). Yu (2015) mentioned that employees in socially responsible firms exhibit a healthier performance as the organizations reward their employees with higher salaries as incentive and motivation to increase their sales and net income. Meanwhile, Shuli \& Suwandee (2017) found that employees perceived CSR has significant impact on employee performance.

The study conducted by Chaudhary (2020) involving Indian business executives revealed a significant influence of employees' CSR perceptions on their job performance and organizational citizenship behaviour (OCB). This study also confirmed that organizations that focus entirely on employee welfare will substantially impact their employees' performance. Employees will also have positive perceptions towards the organization. As a result of a genuine commitment to the cause, organizational involvement in CSR is likely to motivate 
employees to go beyond to fulfil their responsibilities, further the organization's interests and goals, and improve their performance. According to this study, CSR's legal dimension was found to have the most substantial positive influence on both the task and extra-role performance in the present study. These findings implied that employees in India are more sensitive to organizations' legal responsibilities and may respond positively to the legal dimension of CSR through improved job performance and the display of organizationally relevant citizenship behaviours.

Nkeobuna \& Ugoani (2020) examined the impact CSR on the employees in the banking sector in Nigeria. This study revealed that Corporate Social Responsibility positively affects employee empowerment and performance. In this study also, the author designed the model of CSR and employee empowerment beginning with the training and development of employees, followed by motivation, job security, and quality of work life. The result of this study showed that training and development, hiring employees with the necessary technical qualifications and skills, paying employees based on qualifications, relying on performance appraisals as a control tool for promotion, and weeding out poor performers on the job are among the best Corporate Social Responsibility strategies that are necessary for increasing employee empowerment and performance. Looking at the high rate of employee turnover in the banking industry, Nkeobuna \& Ugoani (2020) also suggested that further study should be conducted to examine the role of Corporate Social Responsibility regarding this phenomenon.

Mulej et al (2020) asserted that CSR positively impacts employee performance and motivation. When organizations engage in CSR activities, their employees perceive them as reasonable and fair corporate citizens, which boosts their self-esteem at work. CSR also improves a corporation's reputation among potential employees, impacts employee performance, and enhances corporate prestige and organizational image (Sarfraz et al., 2018). Other than that, (Nazir et al., 2021) mentioned that employees' CSR participation positively affects their sense of purpose (SoP) and experienced meaningfulness (EM) which consequently affects employees' attitudinal and behavioural outcomes such as employee engagement (EE) and job performance (JP).

\section{Conclusion}

In a nutshell, this paper reviewed the impact of CSR on employee performance. Based on the review conducted, this study discovered the mediator and variable of CSR that contributes to the employee performance. Participation in CSR provides employees with a personally meaningful workplace environment, which facilitates engagement and improves actual work performance. Employees also would feel proud to productively work at those companies which follow CSR practices. From the review, it is suggested that there is a need to study the other moderating or mediating variables that could influence CSR and employee performance. Furthermore, this may also encourage companies or organizations to participate in the activities that can positively influence the performance by employees and their and motivation.

\section{References}

Ahmad, I., Donia, M. B., \& Shahzad, K. (2019). Impact of corporate social responsibility attributions on employees' creative performance: The mediating role of psychological safety. Ethics \& Behavior, 29(6), 490-509. 
Albdour, A. A., \& Altarawneh, I. I. (2012). Corporate social responsibility and employee engagement in Jordan. International Journal of Business and Management, 7(16), 89.

Ali, H. Y., Asrar-ul-Haq, M., Amin, S., Noor, S., Haris-ul-Mahasbi, M., \& Aslam, M. K. (2020). Corporate social responsibility and employee performance: The mediating role of employee engagement in the manufacturing sector of Pakistan. Corporate Social Responsibility and Environmental Management, 27(6), 2908-2919. https://doi.org/10.1002/csr.2011

Babatunde, J. H., \& Adeyemi, A. A. (2015). The effectiveness of Islamic banks' corporate social responsibility as perceived by gender in Malaysia: An exploratory research. Journal of Creative Writing, 1(2), 1-18.

Bahari, Z., \& Yusuf, M. Y. (2014). Corporate social responsibility in Islamic banking institutions in Aceh: Analysis of criteria and perception. Journal of Educational and Social Research, 4(2), 390-390.

Bukhari, S. A. A., Hashim, F., \& Amran, A. B. (2020). Determinants and outcome of Islamic corporate social responsibility (ICSR) adoption in Islamic banking industry of Pakistan. Journal of Islamic Marketing.

Carroll, A. B. (1979). A three-dimensional conceptual model of corporate performance. Academy of Management Review, 4(4), 497-505.

Chaudhary, R. (2020). Corporate social responsibility and employee performance: A study among Indian business executives. International Journal of Human Resource Management, 31(21), 2761-2784. https://doi.org/10.1080/09585192.2018.1469159

Darus, F., Yusoff, H., Abang Naim, D. M., Mohamed Zain, M., Amran, A., Fauzi, H., \& Purwanto, Y. (2013). Islamic corporate social responsibility (i-CSR) framework from the perspective of Maqasid al-Syariah and Maslahah. Issues in Social \& Environmental Accounting, 7(2).

Malaysian Workforce Sleepless and Overworked? (2019). Findings from Malaysia's Healthiest Workplace by AIA Vitality 2019 survey reveal that the Malaysian workforce are stressed and sleep deprived. Retrieved from https://www.aia.com.my/en/about-aia/mediacentre/press-releases/2019/malaysian-workforce-sleepless-and-overworked.html

Moayedi, N. N. (2009). Islamic work ethic and Muslim religious beliefs impact on organizational commitment in the workplace. University of Phoenix.

Moher, D., Liberati, A., Tetzlaff, J., \& Altman, D. G. (2009). Preferred reporting items for systematic reviews and meta-analyses: The PRISMA statement. BMJ (Online), 339(7716), 332-336. https://doi.org/10.1136/bmj.b2535

Muda, I., Rafiki, A., \& Harahap, M. R. (2014). Factors influencing employees' performance: A study on the Islamic Banks in Indonesia. International Journal of Business and Social Science, 5(2).

Nazir, O., Islam, J. U., \& Rahman, Z. (2021). Effect of CSR participation on employee sense of purpose and experienced meaningfulness: A self-determination theory perspective. Journal of Hospitality and Tourism Management, 46(August 2020), 123-133. https://doi.org/10.1016/j.jhtm.2020.12.002

Nkeobuna, J., \& Ugoani, N. (2020). Environmental perspectives on corporate social responsibility and its effect on employee empowerment and performance. 6(3), 68-75

Osita-Njoku, A., Anyaoha, O., \& Kamalu, O. (2020). Internal Corporate Social Responsibility and Employee Performance: a Study of Nigeria National Petroleum Corporation, (Nnpc). European Journal of Sociology, 3(1), 45-58. https://doi.org/10.47672/ejs.428

Robinson, P., \& Lowe, J. (2015). Literature reviews vs systematic reviews. Australian and New Zealand Journal of Public Health, 39(2), 103. https://doi.org/10.1111/1753-6405.12393 
Sarfraz, M., Qun, W., Abdullah, M. I., \& Alvi, A. T. (2018). Employees' perception of Corporate Social Responsibility impact on employee outcomes: Mediating role of organizational justice for Small and Medium Enterprises (SMEs). Sustainability (Switzerland), 10(7). https://doi.org/10.3390/su10072429

Story, J. S. P., \& Castanheira, F. (2019). Corporate social responsibility and employee performance: Mediation role of job satisfaction and affective commitment. Corporate Social Responsibility and Environmental Management, 26(6), 1361-1370. https://doi.org/10.1002/csr.1752

Suganthi, L. (2019). Examining the relationship between corporate social responsibility, performance, employees' pro-environmental behavior at work with green practices as mediator. Journal of Cleaner Production, 232, 739-750

Yusuf, M. Y., \& Bahari, Z. B. (2015). Islamic corporate social responsibility in Islamic banking: Towards poverty alleviation. Ethics, Governance and Regulation in Islamic Finance, 73.

Anam, Z. N. M., \& A. A. (2015). The impact of corporate social responsibility on employee performance and cost. Review of Accounting and Finance, 14(3), 262-284. https://doi.org/10.1108/RAF-03-2014-0025 